\title{
STUDY ON TAILINGS DAM OVER-TOPPING FAILURE MODEL TEST AND BREAK MECHANISM UNDER THE RAINFALL CONDITION
}

\author{
Wang Guang-jin, Kang Jing-wen, Du Chao, Tang Yong-jun, Kong Xiang-yun
}

\begin{abstract}
Based on self-designed tailings dam simulation experiment device of tailings dam-break, experimental study of tailings dam failure was carried out under the condition of rainfall. The change rule of infiltration line, the developing process, the mechanism of dam failure and the displacement of the dam body after collapse were obtained and recorded by the rainfall devices, the infiltration line measuring devices, the displacement monitoring devices and the camera. The results are as follows: in the early stage of rainfall, the changes of the infiltration line in the front reservoir and the outside slope of the dam were obviously lagging behind the water level, but in the middle and tail of the reservoir it was not obvious. In the later stage of the rainfall, the lagging phenomenon gradually disappeared, and the change of water level had an obvious effect on the change of infiltration line. At the early stage of the dam failure, seepage and water overflow occurred on the outer slope of the tailings dam, causing local collapse to occur. In the late stages of dam break, the water flew over the dam crest and continued to erode the dam body, thus lead to the dam failure. Under the action of seepage force, the phenomenon of piping occurred in the dam. With the continuous erosion of water flow, the seepage force, floating severe, buoyancy force and pore water pressure were increased, the anti-resistance was weakened and the stability of dam was reduced. After the dam failed, the settlement displacement in the breach was the largest, in addition to the breach, the settlement displacement occurred mainly at the dam abutment. The external expansion occurred mainly in the middle dam and dam foot. The research results provide some valuable guidance and reference for the mechanism analysis of the tailings dam-break, the disaster prevention and controlling when subjected to rainfall.
\end{abstract}

Keywords: anti-resistance; model test; overtopping dam-failure; upstream-type tailings dam

\section{Studija o ispitivanju modela oštećenja jalovinskog nasipa prelijevanjem i mehanizma prekida pod kišnim uvjetima}

Izvorni znanstveni članak Na temelju samo-konstruiranog uređaja za eksperimentiranje simulacijom prekida jalovinskog nasipa, eksperimentalna studija oštećenja nasipa provedena je u kišnim uvjetima. Zakonitost promjene linije infiltracije, proces razvoja tijela nasipa, mehanizam oštećenja nasipa i pomicanje nasipa nakon kolapsa dobiveni su pomoću uređaja za oborine, uređaja za mjerenje infiltracijske linije, uređaja za praćenje pomaka, kamere itd. Rezultati pokazuju sljedeće: u ranoj fazi kiše, promjena linije infiltracije u prednjem umjetnom jezeru i vanjskoj padini nasipa očito je zaostajala za razinom vode, a u sredini i kraju umjetnog jezera to nije uočeno. U kasnijoj fazi kiše, fenomen zaostajanja postupno nestaje, a promjena razine vode ima očiti učinak na promjenu linije infiltracije. U ranoj fazi oštećenja nasipa, curenje i preljev vode dogodili su se na vanjskoj padini nasipa, a došlo je do lokalnog kolapsa. U kasnijim fazama prekida jalovinskog nasipa voda protječe preko nasipa i nastavlja erodirati tijelo nasipa, što dovodi do zatajenja nasipa. Pod djelovanjem propusne sile pojavljuje se fenomen cjevovoda u nasipu. S kontinuiranom erozijom protoka vode, povećana je propusna sila, plutajuća jaka snaga uzgona i tlak vode pora, protu-otpor je oslabio i smanjena je stabilnost nasipa. Nakon oštećenja tijela nasipa, najveće je pomicanje zemlje u proboju, pored proboja, pomicanje zemlje uglavnom se događa kod potpore nasipa. Vanjska ekspanzija uglavnom se javlja u sredini nasipa i podnožju nasipa. Rezultati istraživanja pružaju neke smjernice i referentnu vrijednost za analizu modela i mehanizma prekida jalovinskog nasipa i sprječavanje katastrofe te kontrole pod kišnim uvjetima.

Ključne riječi: nadmorski oblik jalovinskog nasipa; oštećenje jalovinskog nasipa prelijevanjem; protu-otpor; testni model

\section{Introduction}

The tailings pond is a dangerous source of man-made debris flow with high potential energy. Various natural and man-made unfavourable factors threaten its safety, tailings often contain harmful substances [1,2]. During all the triggering factors of the tailings dam failure, the main causes of the accident are due to unusual rainfall and mismanagement [3-5]. Liquefaction of the tailings deposits was induced by the strong shaking during the earthquake $[6,7]$. Seepage and migration of water is one of the most important factors which influence the stability of tailings dam [8]. The influence of atmospheric rainfall on the dam seepage is obvious, the heavier the rainfall, the higher the infiltration line, the more disadvantageous to the dam stability [9]. Tailings are non-sticky or less viscous bulk soils, which are easily led to be liquefied [10-13].

For the tailings dam failure model and mechanism, there is a block effect in the process of tailings dam break [14]. Tailing dam failure belongs to counter-current traction model, the destruction of the dam generally involves three stages [15]. Tailings dam failure mode is generally counter-current progressive, damage first occurred at the foot, and then evolved to the upstream. It shows traction-type development [16]. Breach flushing flow increased with the reservoir water level decreasing in the early dam break, the time that the tailings dam break occurred was related to the upstream flow [17]. If the infiltration line is too high, it will make the dam body, the abutment and the combination of different parts of seepage and water outflow resulting in piping, eventually leading to dam break [18]. Usually, the infiltration line of the fine-grained tailings is higher than that of the coarse-grained tailings, and moreover, the fine-grained tailings are of poor seepage ability [19]. In addition, tailing dam displacement is also related to the saturation degree of the dam. The higher the infiltration line, the higher the sliding displacement of the tailings dam, and the failure degree of the breach depends on the dam erosion [20].

Tailings dam research involves the interdisciplinary fields of soil mechanics, hydraulics and sediment dynamics, which brings difficulty to the research of tailing dam collapse mechanism [21]. The model test results of tailing dam failure cannot only make up the limitation of amount and reliability of dam break data analysis, but also provide validation data for numerical 
simulation, as well as have an irreplaceable role in numerical simulation of dam-break mechanism research and dam-break data analysis [22]. At the same time, there is not much research about model test on the mechanism of the tailings dam break caused by rainfall. So, in this paper, indoor tailings dam over-topping model experiments were carried out under the conditions of rainfall in the reservoir. The change rule of the infiltration line, the process and mechanism of overtopping damfailure, the displacement of the dam after collapse were analyzed. The research results will be of great significance for understanding the mechanism of dam failure and the early warning before tailings dam failure.

\section{Model test of tailings dam failure \\ 2.1 Experimental content}

The indoor model tests of the tailings dam break were carried out, and the main contents are as follows: Monitor and obtain the change rule of the infiltration line before the dam break; Explore the development process and mechanism of tailings dam break; Obtain the law of dam displacement after dam failure.

Using the upstream tailings dam as the research object, the model is scaled at 1: 50 reduced. The initial dam is with mixed earth-rock, its size is $3 \mathrm{~m}$ long, $0.08 \mathrm{~m}$ high, $0.12 \mathrm{~m}$ wide on the top and $0.47 \mathrm{~m}$ on the bottom. The ratio of the accumulation dam slope is $1: 1.25$, the ratio of outer slope is 1: 3.125. The size of the accumulation dam is the same as the initial dam, and the model of the tailings dam is shown in Fig. 1.

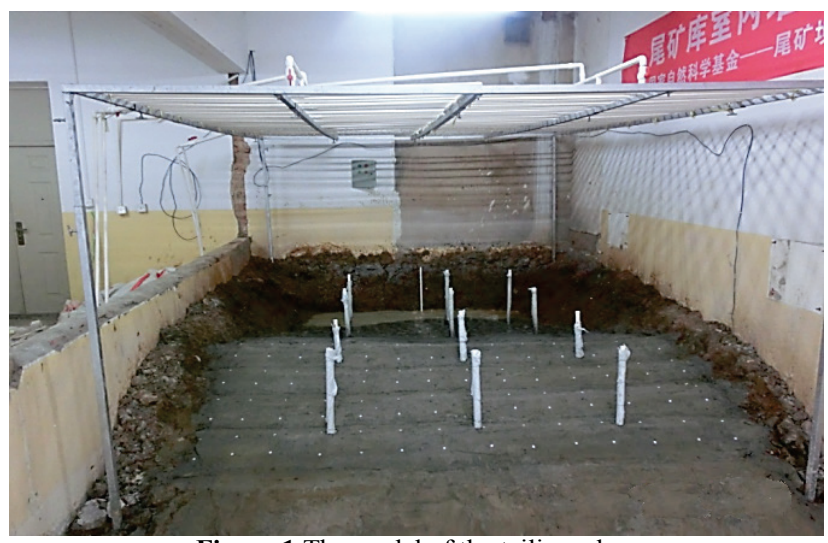

Figure 1 The model of the tailings dam

\subsection{Test materials}

The similarity relationship related to the prototype between the test model and the physical quantity was analysed. The dam-break process involves hydromechanics, soil mechanics, sediment kinematics and other similar problems, the similarity relationship derived from all aspects is usually incompatible. Test model cannot meet all the similarity conditions. Ignoring the general similarity, the similarity criterion will be relaxed, then the main parameters of the prototype can be met, and the similar model can be made [23, 24]. The particle size distribution of model sand is shown in Tab. 1.

Table 1 The particle size distribution of tailings

\begin{tabular}{|c|c|c|c|c|c|c|}
\hline $\begin{array}{c}\text { Particle size } \\
(\mathrm{mm})\end{array}$ & $<0.074$ & $<0.1$ & $<0.25$ & $<0.5$ & $<1$ & $<2$ \\
\hline $\begin{array}{c}\text { Percentage } \\
(\%)\end{array}$ & 15.97 & 29.54 & 70.31 & 94.05 & 99.59 & 100 \\
\hline
\end{tabular}

\subsection{Model test device}

The indoor tailings dam model experimental device system is shown in Fig. 2. The device system mainly includes:

Rainfall device. The rainfall device uses the spray type rainfall pattern by using a diameter of $16 \mathrm{~mm}$ PVC straight pipe as a water pipe; every $8 \mathrm{~cm}$ in the $\mathrm{PVC}$ pipe a hole is drilled with diameter of $0.5 \mathrm{~mm}$; water spouted from the hole, which simulates rainfall. The variation rule of rainfall with time can be recorded.

Monitoring system. The system is mainly composed of infiltration line monitoring system, reservoir water level monitoring system, displacement monitoring system and the camera. The change rule of dam infiltration line and reservoir water level during rainfall process were record by infiltration line monitoring system and the reservoir water level monitoring system. Displacement monitoring system can measure the displacement of dam body before and after the dam break, and the camera can record the dam break and dam displacement of the tailings dam.

Ore drawing equipment. Ore drawing equipment is mainly composed of a mixer and the ore drawing tubes, which is used to simulate the process of ore drawing.

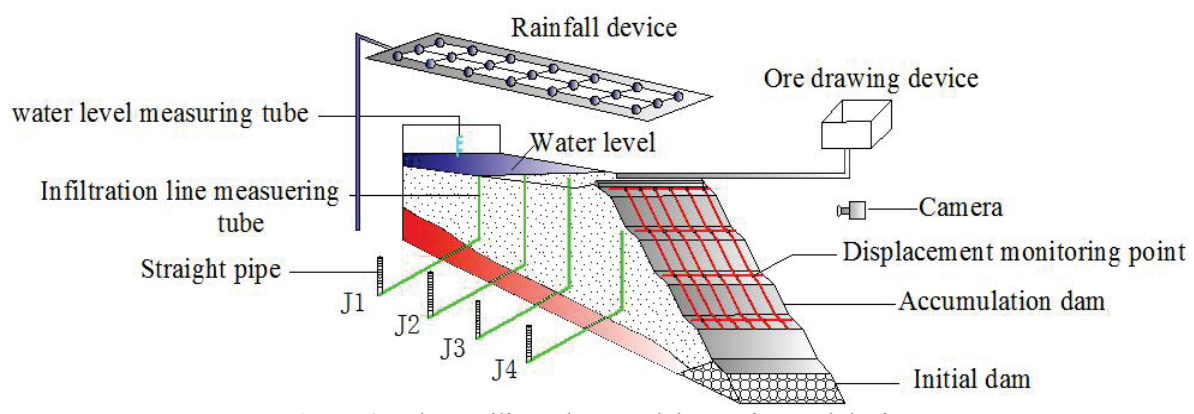

Figure 2 Indoor tailings dam model experimental device

\subsection{Infiltration lines monitoring system}

The arrangement of infiltration lines monitoring instrument is shown in Fig. 3.
Four infiltration line tubes were arranged along the longitudinal section of the central part of the dam body, the bottom of the infiltration line pipe was connected with PVC straight pipe, the PVC pipe was connected with 
transparent straight pipe with scale in the outside dam. Through the water level of the transparent tube in the outside dam, one can measure the height of the infiltration line. In order to make a distinction easily, the infiltration lines were numbered $\mathrm{J} 1, \mathrm{~J} 2, \mathrm{~J} 3, \mathrm{~J} 4$ from the inner reservoir to the outside reservoir. $\mathrm{J} 1$ was buried in the reservoir tail, J2 was buried in the middle reservoir, J3 was buried in front of the reservoir, J4 was buried in the dam outside slope. The distance between the four infiltration lines from inner to the outer was $0.6 \mathrm{~m}, 0.5 \mathrm{~m}$ and $0.5 \mathrm{~m}$ respectively. The water level in the reservoir was directly measured by the water level measuring tube.

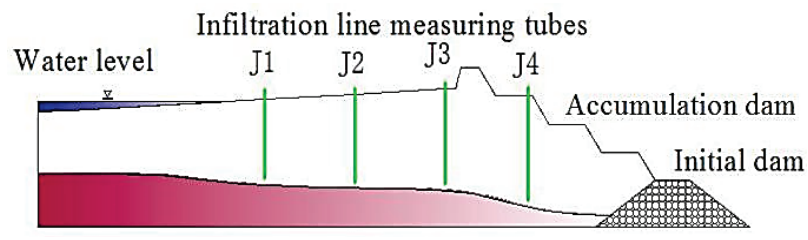

Figure 3 The arrangement of infiltration line monitoring instrument

\subsection{The dam displacement measurement}

The dam displacement measuring layout is shown in Fig. 4. The monitoring line is arranged at the crest of each sub-dam. Six monitoring points were arranged for each monitoring line, 24 displacement monitoring points are arranged in the four sub-dams, a total of 24 displacement monitoring points were arranged in the four sub-dams, as shown in Fig. 4, each of monitoring points is numbered. The reference lines of the displacement were arranged on the wall, and the distance between the displacement monitoring points and the reference lines were respectively measured before and after the collapse. By comparing the change of distance before and after the collapse, the displacement of dam body can be obtained.

\begin{tabular}{|c|c|}
\hline Four sub-dam & 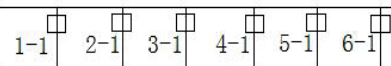 \\
\hline Three sub-dam & 1-2 2-市 3-2 4-2 5-2 6-2 \\
\hline Second sub-dam & 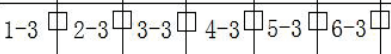 \\
\hline First sub-dam & ${ }_{1-4} \Phi_{2-4} \Phi_{3-4} \Phi_{4-4} \Phi_{5-4} \Phi_{6-4}$ 中 \\
\hline Initial dam & \\
\hline
\end{tabular}

Figure 4 The dam displacement measuring layout

\section{The variation law of infiltration line}

Understanding the change rule of the infiltration line is an important factor to influence the safety of tailings dam. The change of the infiltration line of dam is generally determined by the speed of the water level change in the reservoir, the permeability coefficient and the water supply degree of the soil body and other factors. The change of infiltration line is the most sensitive trigger to the change of water level in the reservoir [25]. Therefore, in this experiment, it is assumed that when encountering heavy rain, the tailings facilities cannot be normally discharged because of existing problems that will lead to tailings dam overtopping. In the course of rainfall, the height of the water level and the height of the infiltration line are measured every 10 minutes. The height of the infiltration line and the water level change with time is shown in Fig. 6.

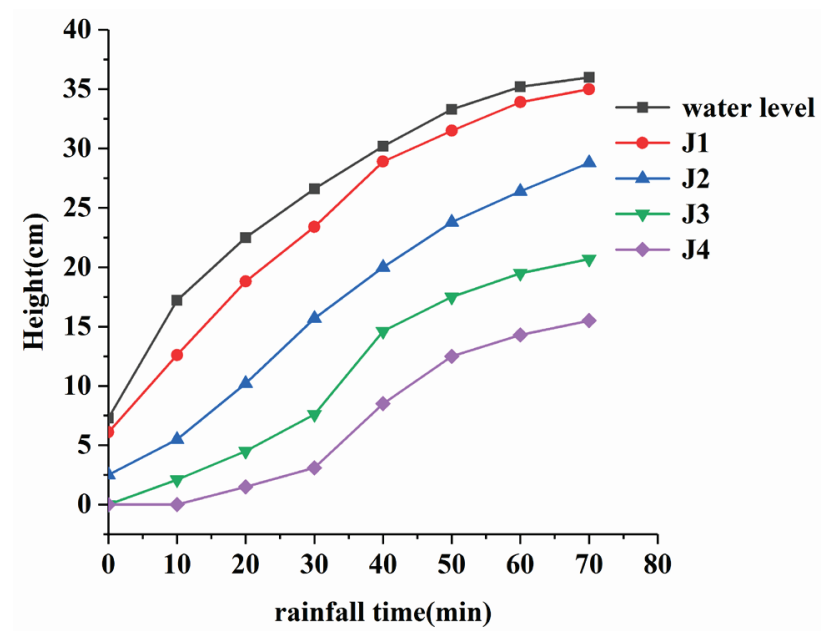

Figure 5 The height of the infiltration line and the water level change with the rainfall time

Because of the tailings pond drainage facilities having problems, the water in the reservoir cannot be discharged to the outside. It can be seen from Fig. 5 that there is almost a linear relationship between water level change and rainfall time. The water level in the reservoir is increased with the rainfall time increase. The infiltration lines height of $\mathrm{J} 1, \mathrm{~J} 2, \mathrm{~J} 3$ and $\mathrm{J} 4$ were increased gradually with the rising of the water level, which indicated that the change of the water level in the reservoir had an obvious influence on the change of the infiltration line. The values of the infiltration lines at $\mathrm{J} 1$, $\mathrm{J} 2, \mathrm{~J} 3$ and $\mathrm{J} 4$ were $6.1 \mathrm{~cm}, 2.5 \mathrm{~cm}, 0 \mathrm{~cm}, 0 \mathrm{~cm}$ respectively at the beginning of the rainfall. As the rainfall continued, the infiltration lines at $\mathrm{J} 1$ and $\mathrm{J} 2$ were obviously affected by water level rise, and the rising rate of $\mathrm{J} 1$ was almost the same as the rising rate of water level. The rainfall simulation experiment was carried out immediately after the ore drawing test was completed. The moisture content of the tailings sand in the accumulation dam is relatively high. Rain water on the dry beach surface not only constantly converges to the reservoir, but also there is a part of the rain directly from the dry beach surface slowly infiltrated into the deep tailings, and closer to the end of the reservoir, the water infiltrated more. Because of such a higher degree of tailings saturation in the reservoir tail and middle, in the early period of rainfall, the advancing speed of the water seepage to $\mathrm{J} 1$ and $\mathrm{J} 2$ was fast, the height of the infiltration lines at $\mathrm{J} 1$ and $\mathrm{J} 2$ lagging behind the water level was not obvious. Because the water from the reservoir tail seepage to the outer slope of the dam will take some time, the infiltration lines at $\mathrm{J} 3$ and $\mathrm{J} 4$ do not obviously change with the increase of the water level. The height of infiltration lines at $\mathrm{J} 3$ and $\mathrm{J} 4$ lagging behind the height of water level is obvious, that of $\mathrm{J} 4$ more obvious than $\mathrm{J} 3$. The lag time is mainly related to the permeability coefficient, moisture content, pore pressure and the difference of loose degree between tailings particles. When the reservoir water flows to the reservoir tail and dam slope, the height of infiltration lines at $\mathrm{J} 3$ and $\mathrm{J} 4$ begins to rise, the rising rate is accelerating, which is almost consistent with the rising rate of water level. 
The change of water level in the reservoir has a great influence on the infiltration lines, and the infiltration lines will rise gradually with the reservoir water level increase. Infiltration lines influence the lifeline of tailings dam safety operation. When the infiltration lines are increased by $10 \%$, the safety factor of the dam stability will be reduced by about 0.02 [26]. Therefore, when the heavy rainfall and flood occur, if the corresponding effective measures are not taken, the infiltration lines will increase with the rising of water level in the reservoir. It will also shorten the seepage path and directly affect the seepage field boundary of the tailings dam, which is unfavourable to the stability of the dam body.

\section{The over-topping dam failure test under the conditions of rainfall}

\subsection{The process of over-topping dam-failure}

Based on the observation of dam-break model, the dam-break process is shown in the following Fig. 6, and the dam-break process is as follows:

The seepage of the tailings and the water overflow occurred at the dam site during the rising of the water level. At the beginning of the water overflow, the overflow has a very low sand content, and the speed of water flow is also slow. With the increasing of overflow water, some small gullies caused by water erosion are formed on the dam surface. There is swamping or surface flow at the downstream dam slope, and the outflow water takes away the tailings of the downstream dam and forms the small collapsed.

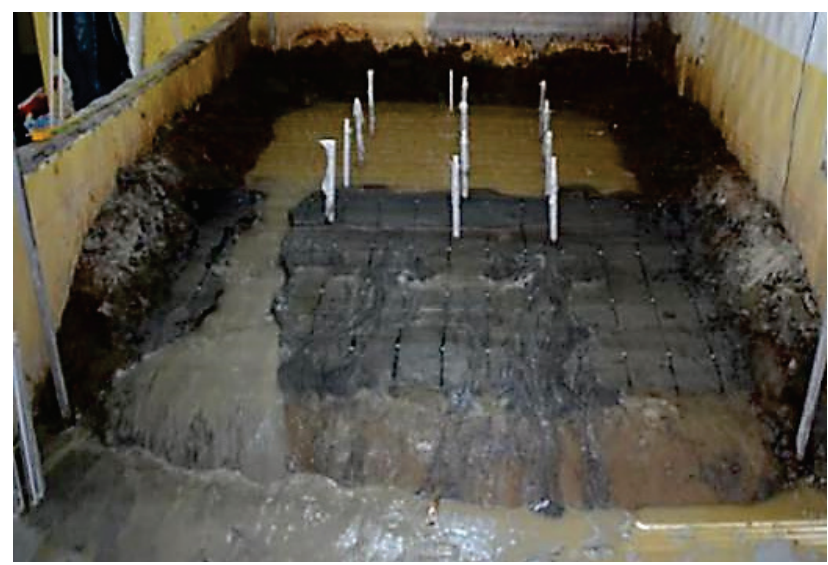

Figure 6 The process of dam-break

With the rainfall continuing, water level is rising, the water flows over the lowest point of the crest and the overflow phenomenon occurs at the left dam crest and causes the formation of breach. The water flow cross section of the breach is small, the water containing tailings is very low and close to the clear water flow. Because of the small flow velocity, the erosion intensity is weak, and the tailings which are washed up by water flow continuously into the water and quickly exceed the sediment carrying capacity of the current. The duration of this stage is shorter, mainly with vertical erosion, accompanied by small lateral broadening [27].

The water overflows the top of the breach, the top of the breach is completely eroded, and the cross-section of the breach increases, the breach is deepened and accompanied by a slight lateral broadening. After the breach through, the amount of water in the breach increases and water erosion enhances. The accumulation of some tailings in the breach is transported to the downstream by the water flow, and the loose tailings on the dam surface flow to the dam foundation by the tailings flow erosion.

In the upstream of the dam, the amount of water in breach is large, but the rate of flow is small, erosion mainly occurs in the middle and downstream of the dam. The cut effect of the water flow is obvious in the downstream, the water flow erodes the downstream slope that leads to the downstream slope foot collapse, and the scarp appears in the downstream dam. At the same time, the water continuously washes the foot of the breach, causing both sides of the breach slope collapse. The breach in the downstream surface to the trumpet-like expansion and the downstream accumulation of tailings increases rapidly.

The breach flow increased rapidly and the water cutting effect was more obvious. Breach slopes of the dam have collapsed rapidly, the water flow and the water erosion reach the maximum, and a large number of tailings at the breach continued to be carried to the downstream by water erosion. The water level in the reservoir is decreased rapidly. The erosion is basically finished, the dam body is destroyed completely. A lot of tailings in the downstream of the dam were a fan-shaped accumulation after the dam collapse, similar to debris flow.

\subsection{The mechanism analysis of dam failure}

According to the whole test process, the whole process of dam seepage break can be divided into the following stages.

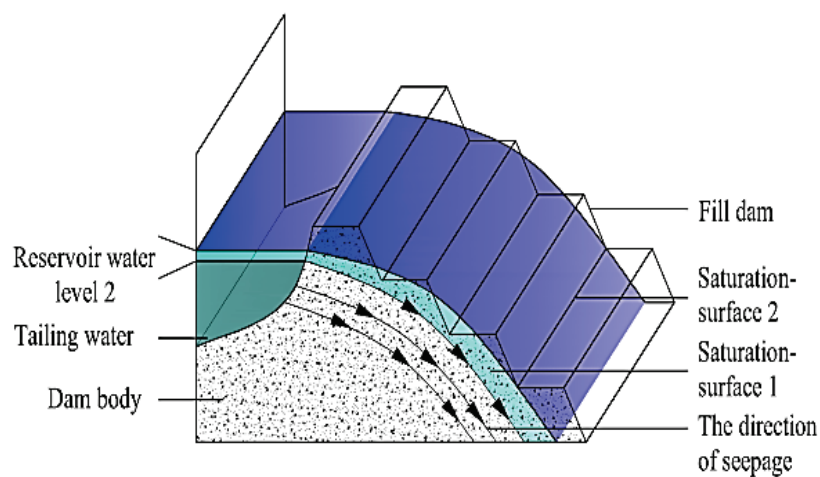

Figure 7 The seepage within tailings dam

Seepage break appears on the dam surface. With the reservoir water level rising, the infiltration lines are also rising gradually, the water continuously infiltrates the dam tailings during the lifting process, and a seepage force is applied to the tailings particles. The direction of seepage force is shown in Fig. 7.

Assuming that the direction of seepage force is consistent with the potential slip surface and the potential slip surface is parallel with the saturated surface. When unit dam is divided into slices it makes the equipotential surface as interface, as shown in Fig. 8. 


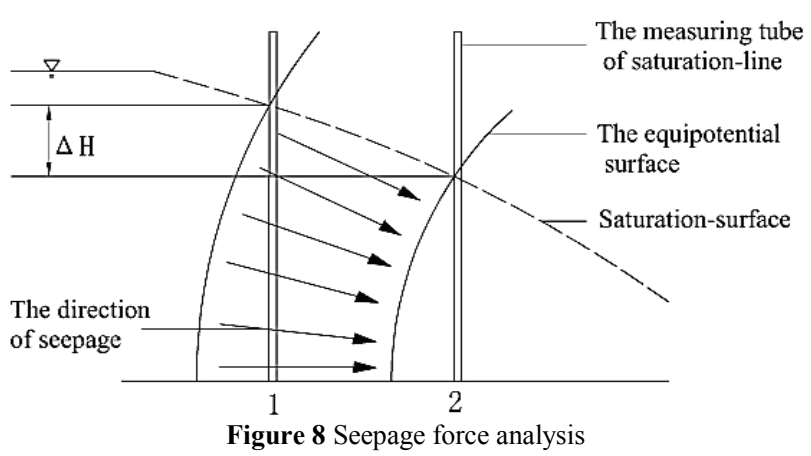

Position 1 and position 2 correspond to an equipotential surface and make the water level of the saturated surface as water head $\left(H_{1}, H_{2}\right)$, the distance between Position 1 and Position 2 is $L$. The hydraulic gradient and the per unit volume seepage force can be described as follows:

$$
\begin{gathered}
i=\frac{\Delta H}{L}=\frac{H_{1}-H_{2}}{L} \\
j=\gamma_{w} \frac{H_{1}-H_{2}}{L}
\end{gathered}
$$

where $i$ is hydraulic gradient, $j$ is the per unit volume seepage force

The seepage force is a body force and its dimension is the same with $\gamma_{w}\left(\gamma_{w}\right.$ is the density of water bulk), the total seepage force is shown by the following calculation equation:

$$
J=V_{s} \gamma_{w} \frac{H_{1}-H_{2}}{L}
$$

Under the action of seepage force, when the tailings gradation is poor, the fine tailings are moved in the voids formed by coarse particles of tailings. With the continuous expansion of the gap, the rate of seepage increases, the coarse particles being gradually taken away by the water flow, eventually leading to the formation of the seepage pipeline in the dam, is resulting in local instability and collapse of the dam.

Seepage break increased. When the saturation surface is over the dam surface, it produces obvious phenomena of seepage break. The relative position of saturation surface and dam surface is shown in Fig. 9.

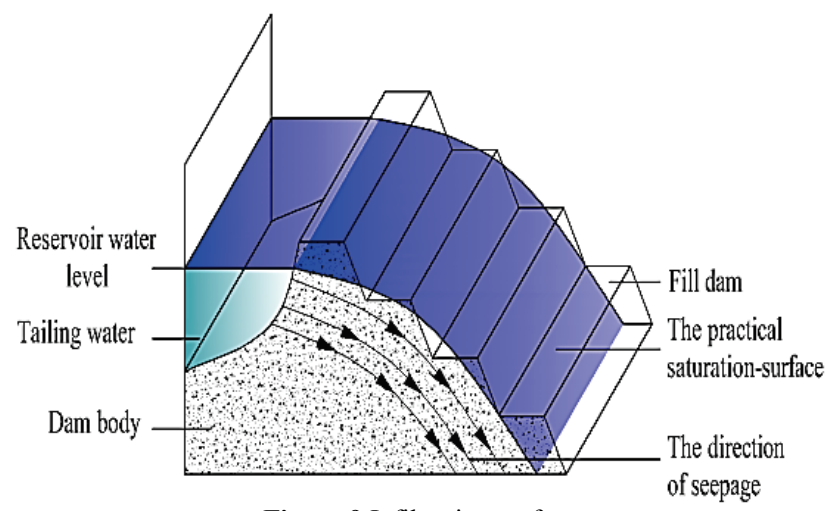

Figure 9 Infiltration surface
The break by seepage started from saturation surface, when the saturation surface over part of the dam surface, the unit tailings located at the saturation surface influenced by the upper water-free layer and the down saturated layer, the detail force analysis is shown in Fig. 10 .

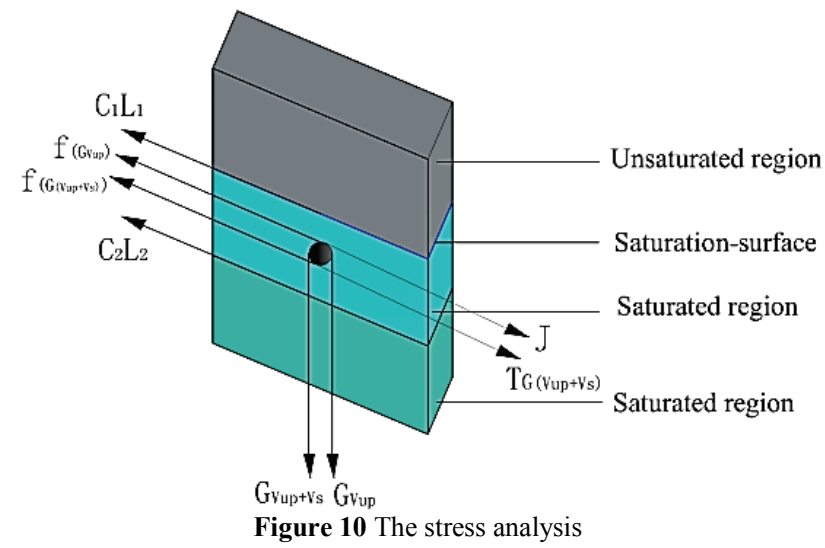

The anti-resistance includes the frictional resistance from overlying soil layer and the cohesive force from the up and down interface, so the effective anti-resistance equations from the unit tailings dam dead-weight are as follows:

$$
\begin{aligned}
& R=\gamma V_{u p} \cos \alpha_{1} \tan \phi_{1}^{\prime}+c_{1}^{\prime} L_{1}+ \\
& +\left(\gamma^{\prime} V_{s}+\gamma V_{u p}\right) \cos \alpha_{2} \tan \phi_{2}^{\prime}+c_{2}^{\prime} L_{2},
\end{aligned}
$$

where $R$ is effective anti-resistance, $\gamma$ is tailings bulk density, $\gamma^{\prime}$ is tailings floating bulk density, $V_{s}$ is volume of saturated tailings, $V_{u p}$ is volume of overlying tailings, $\phi_{1}^{\prime}$, $\phi_{2}^{\prime}$ are effective internal friction angle of upper and down tailings, $\alpha_{1}, \alpha_{2}$ are angle of two slip surfaces and horizontal plane, $c_{1}^{\prime}, c_{2}^{\prime}$ are effective cohesive force of upper and down tailings; $L_{1}, L_{2}$ are base line length of different slices, let $L_{1}=L_{2}$.

As can be seen from Fig. 10, the effective sliding force includes component force of unit volume tailings gravity and tailing water seepage force. The equations of effective sliding force are as follows:

$T=\left(\gamma^{\prime} V_{s}+\gamma V_{u p}\right) \sin \alpha_{2}+V_{s} \gamma_{w} \frac{H_{1}-H_{2}}{L}$

The effective anti-resistance and the effective sliding force are opposite. In the process of reservoir water level rising, the water-seepage action makes the effective internal friction angle $\left(\phi_{1}^{\prime}, \phi_{2}^{\prime}\right)$ and the effective cohesive force $\left(c^{\prime}{ }_{1}, c_{2}^{\prime}\right)$ of upper and down tailings layer decrease, so that makes $\mathrm{R}$ decrease, when $R<T$, the tailings leak out gradually. When water-saturated tailings are reduced, the dam crest will subside because of deadweight, then the water level in the reservoir will be higher than the dam crest.

Dam settlement and erosion. The effect of seepage break makes part of dam crest under water level in the reservoir, then the breach occurs in the dam crest. The reservoir water flows from dam breach and carries a little 
of tailings. Fig. 11 is the description of settlement features.

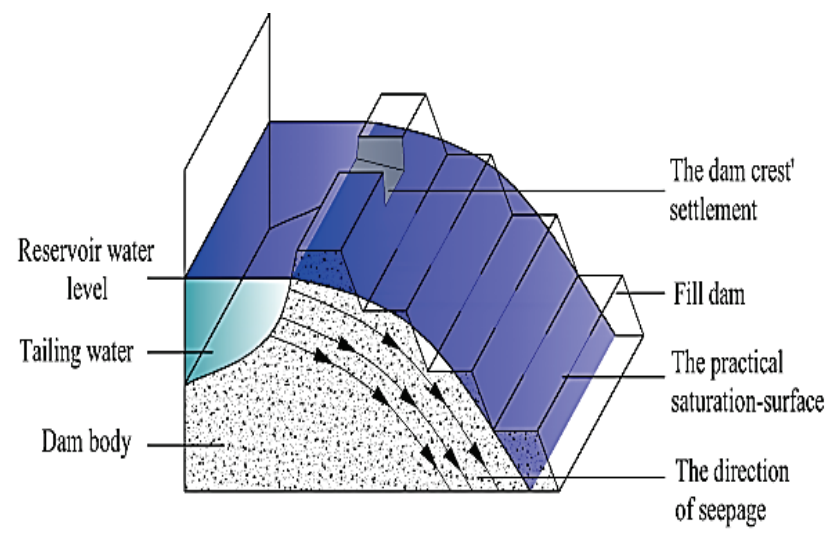

Figure 11 Part settlement of dam crest

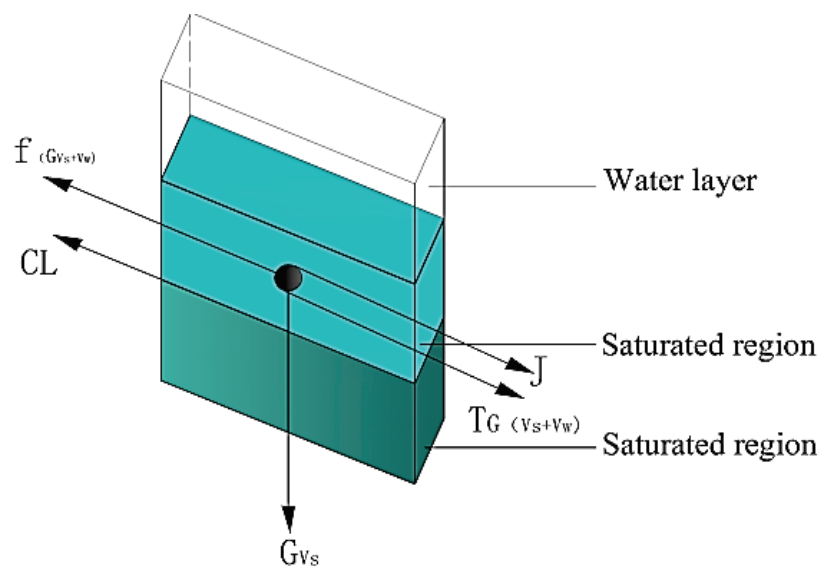

Figure 12 Stress analysis of tailings

When the water level in the reservoir is higher than the breach, the upper part of the tailings for the water layer. At this time, the tailings of the force shown in Fig. 12.

The effective anti-resistance:

$R=\left(\gamma^{\prime} V_{s}+\gamma_{w} V_{w}\right) \cos \alpha \tan \phi^{\prime}+c^{\prime} L$.

(6)

The effective sliding force:

$T=\left(\gamma^{\prime} V_{s}+\gamma_{w} V_{w}\right) \sin \alpha+V_{s} \gamma_{w} \frac{H_{1}-H_{2}}{L}$, where $\gamma_{w}$ is tailings water bulk density; $V_{w}$ is the upper tailings water volume

The breach is rapidly expanding. With the water at the breach flowing out constantly, under the action of water erosion and transport, the dam tailings are taken away by the water, forming a number of gullies, as shown in Fig. 13.

With the continuous expansion of the breach, the water flow increasing rapidly, the depth of the breach deepening and the breach continuing to widen, the tailings are constantly taken away by the water. The development trend of the breach is proportional to the flow rate and the flow, when the reservoir water does not increase, the water level in the reservoir is reduced to a level of breach, the dam break process slows down until it stops.

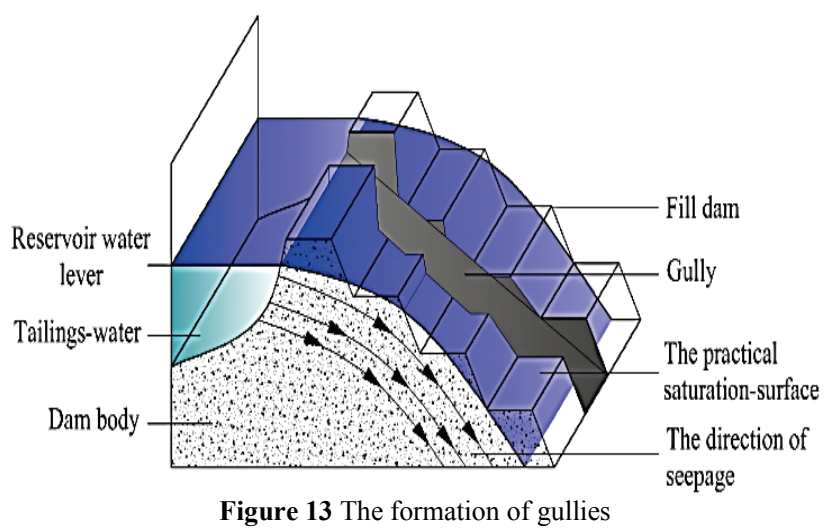

\section{The law of dam displacement after dam failure}

Displacement of the dam includes horizontal settlement and external expansion. In this experiment, the distance between the fixed points on the wall and the measured points on the slope of the dam is measured by the laser range finder. If the distance after dam break is smaller than that before dam break, it means that external expansion happened. If the distance after dam break is larger than that before the dam break, it indicates that the settlement occurred. After the dam break, the distance between the fixed point on the wall and the measured points on the slope of the dam is measured by the laser range finder as shown in Tab. 2. The difference in Tab. 2 means the distance after the dam failure is subtracted from the distance before the dam failure.

Table 2 Displacement of dam body before and after dam break

\begin{tabular}{|c|c|c|c|c|c|c|c|c|c|c|c|}
\hline \multirow{2}{*}{$\begin{array}{c}\text { Monitoring } \\
\text { Points }\end{array}$} & \multicolumn{2}{|c|}{ Height (m) } & \multirow[b]{2}{*}{ Difference } & \multirow{2}{*}{$\begin{array}{c}\text { Monitoring } \\
\text { Points }\end{array}$} & \multicolumn{2}{|c|}{ Height (m) } & \multirow[b]{2}{*}{ Difference } & \multirow{2}{*}{$\begin{array}{l}\text { Monitoring } \\
\text { Points }\end{array}$} & \multicolumn{2}{|c|}{ Height (m) } & \multirow[b]{2}{*}{ Difference } \\
\hline & $\begin{array}{l}\text { Before } \\
\text { Failure }\end{array}$ & $\begin{array}{c}\text { After } \\
\text { Failure }\end{array}$ & & & $\begin{array}{l}\text { Before } \\
\text { Failure }\end{array}$ & $\begin{array}{c}\text { After } \\
\text { Failure }\end{array}$ & & & $\begin{array}{l}\text { Before } \\
\text { Failure }\end{array}$ & $\begin{array}{c}\text { After } \\
\text { Failure }\end{array}$ & \\
\hline $1-1$ & 3.91 & 4.22 & 0.31 & $2-1$ & 3.99 & 4.01 & 0.02 & $3-1$ & 3.82 & 4.22 & 0.4 \\
\hline $1-2$ & 4.39 & 4.93 & 0.54 & $2-2$ & 4.53 & 4.55 & 0.02 & $3-2$ & 4.49 & 4.9 & 0.41 \\
\hline $1-3$ & 4.94 & 4.98 & 0.04 & $2-3$ & 4.95 & 4.97 & 0.02 & $3-3$ & 4.94 & 4.9 & -0.04 \\
\hline $1-4$ & 5.13 & 5.15 & 0.02 & $2-4$ & 5.26 & 5.37 & 0.11 & $3-4$ & 5.21 & 4.93 & -0.28 \\
\hline $4-1$ & 3.87 & 4.14 & 0.27 & $5-1$ & 4.12 & 4.15 & 0.03 & $6-1$ & 3.74 & 3.82 & 0.08 \\
\hline $4-2$ & 4.46 & 4.43 & -0.03 & $5-2$ & 4.24 & 4.27 & 0.03 & $6-2$ & 4.9 & 4.81 & -0.09 \\
\hline $4-3$ & 4.95 & 4.89 & -0.06 & $5-3$ & 4.88 & 4.83 & -0.05 & $6-3$ & 4.98 & 4.91 & -0.07 \\
\hline $4-4$ & 5.23 & 5.02 & -0.21 & $5-4$ & 5.28 & 5.19 & -0.09 & $6-4$ & 5.35 & 5.47 & 0.12 \\
\hline
\end{tabular}


As can be seen from Tab. 2, after the dam failure, the settlement and external expansion occurred. The dam settlement occurred in 1-1 1-4 and 2-1 2-4, in addition to the two places, the dam settlement occurs mainly in the abutment, and the dam external expansion occurs mainly in the middle dam and dam foot. The value of dam body displacement settlement reached the maximum in the 11 1-4 (here is the breach), the flow erosion is the strongest, and the tailings are washed away by the discharged water to the downstream of the dam, leading to the value of settlement of the breach reach maximum. From the difference of the breach, it can be seen that the settlement of the upper of the dam is the largest after the dam break, the second is the dam abutment, and the lower part and foot is the minimum. As the water level is rising, the infiltration lines are also rising gradually and are lifted from the dam foot to the middle of the dam body, resulting in the hydrostatic pressure and seepage pressure being increased at the middle of the dam body, which is liable to cause the occurrence of flow sand or piping, and the dam body expanding in this process. After the collapse of the dam, the external expansion is more obvious.

The dam body expansion also mainly occurred in the middle and foot of the dam. From the process of dambreaking, it can be seen, the phenomenon of overflow and collapse occurred in the middle of the dam before dam overtopping break. It is also further explained that the higher the water head, the greater the seepage pressure. The tailings sand at the abutment are saturated by the overflow; the weight of the tailings is increased, with the dam body having a certain external expansion, leading to settlement at the abutment being more obvious after the collapse.

\section{Conclusion}

In this paper, the experimental study on dam-break model of tailing pond in the condition of rainfall in the reservoir was carried out by simulating experimental device of tailings dam. The experimental results show that the change of water level has obvious effect on the change of infiltration line, but the change of infiltration line lags behind water level change. Water level has a more obvious effect on the infiltration line in the middle and tail of the reservoir than in the front and the dam outside. In the process of dam failure, tailings seepage and water overflow occurred on the outer slope of the tailings dam, and local collapse occurred. With the water flowing over the dam crest, the dam body continues to erode leading to the dam failure. With the continuous erosion of the water flow, the seepage force, buoyancy force and pore water pressure are increased, the anti-resistance is weakened and the dam stability is reduced. After the collapse of the dam, the settlement of the dam is the largest in the breach, in addition to breach, the settlement displacement mainly occurs at the abutment, and the external expansion of the dam mainly occurs in the middle dam and dam foot department.

\section{Acknowledgements}

The authors acknowledge the collective support granted by the National Natural Science Foundation of China (Grant No 41602307, Grant No 51234004), National key research and development plan (Grant No 2017YFC0804601), Open issue with the key laboratory of mine geological hazards mechanism and control (Grant No KF2017-10), Research and development project of CSCEC Science \& Technology (Grant No CSCEC-2017Z-4), Yunnan Copper Group School-enterprise funds (Grant No 2015YT05), the technology projects of key technologies with the major accident of safety production in 2016 (Grant No yunnan-001-2016AQ).

\section{References}

[1] Zhao, T. L.; Chen, S. S.; Zhong, Q. M. Advances in studies of tailing dam break mechanism and process. // HydroScience and Engineering. 1 (2015), pp. 105-111.

[2] Kossoff, D.; Dubbin, W. E.; Alfredsson, M.; Edwards, S. J.; Macklin, M. G.; Hudson-Edwards, K. A. Mine tailings dams: Characteristics, failure, environmental impacts, and remediation. // Applied Geochemistry. 51(2014), pp. 229245. https://doi.org/10.1016/j.apgeochem.2014.09.010

[3] Azam, S.; Li, Q. Tailing dam failure: a review of the last one hundred years. // Waster GEO Technics. 28, 4(2010), pp. 50-53.

[4] M. Rico; G. Benito; A. Díez-Herrero. Floods from tailings dam failure. // Journal of Hazardous Material. 154, 1 (2008), pp. 79-87. https://doi.org/10.1016/j.jhazmat.2007.09.110

[5] Shakesby, R. A.; Whitlow, J. R. Failure of a mine waste dump in Zimbabwe: Causes and consequences. // Environmental Geology and Water Sciences. 8, 2(1991), pp 143-153. https://doi.org/10.1007/BF01704668

[6] Kenji Ishihara; Kennosuke Ueno; Seishi Yamada; Susumu Yasuda; Takeshi Yoneoka. Breach of a tailings dam in the 2011 earthquake in Japan. // Soil Dynamics and Earthquake Engineering. 68(2015), pp. 3-22. https://doi.org/10.1016/j.soildyn.2014.10.010

[7] Chakraborty, D.; Choudhury, D. Investigation of the behavior of tailings earthen dam under seismic conditions. // American Journal of Engineering and Applied Sciences. 2, 3(2009), pp. 559-564. https://doi.org/10.3844/ajeassp.2009.559.564

[8] Zandarín, M. T.; Decop, L. A.; Rodríguez, R.; Zabala, F. The role of capillary water in the stability of tailing dams. // Engineering Geology. 105, 1-2(2009), pp. 108-118. https://doi.org/10.1016/j.enggeo.2008.12.003

[9] Yin, G. Z.; Wei, Z. A.; Wan, L. Numerical simulation of underground seepage field in Longdu tailings reservoir. // Rock and Soil Mechanics. 24, A2(2003), pp. 25-28.

[10] Lade, P. V.; Yamamuro, J. A. Evaluation of static liquefaction potential of silty sand slopes. // Canadian Geo technical Journal. 48, 2 (2011), pp. 247-264. https://doi.org/10.1139/T10-063

[11] Anderson, C. D.; Eldridge, T. L. Critical state liquefaction assessment of an upstream constructed tailings sand dam. // Proceedings of the $14^{\text {th }}$ International Conference on Tailings and Mine Waste, 2012, pp. 101-112.

[12] Bedin, J.; Schnaid, F.; Dafonseca, A. V. Gold tailings liquefaction under critical state soil mechanics. // Géotechnique. 62, 3(2012), pp. 263-267. https://doi.org/10.1680/geot.10.P.037

[13] Liu, Y.; Zhao, X. T.; Wu, S. C. Analysis of Static Liquefaction and Numerical Simulation for tailings pond under high depositing rates. // Chinese Journal of Rock Mechanics and Engineering. 33, 6(2014), pp. 1158-1168. 
[14] Zhao, Y. S.; Jing, X. F.; Zhou, X.; Cai, Z. Y.; Liu, K. H. Experimental study on blocking action of bar strip on tailings dam overtopping. // China Safety Science Journal. 1, (2016), pp. 94-99.

[15] Zhang, L. T.; Qi, Q. L.; Li, Q.; Zhang, S. X.; Liu, Y. B. (2016). Experimental model study on dam break and evolution law of tailings pond. // Journal of Hydraulic Engineering. 47, 2(2016), pp. 229-235.

[16] Jing, X. F.; Yin, G. Z.; Wei, Z. A; Li, X. S.; Wang, M. L. Model experimental study of collapse mechanism and broken mode of tailings dam. // Rock and Soil Mechanics. 32, 5(2011), pp. 1378-1384.

[17] Zhou, Y.; Zhang, Q. Simulation of process of flood routing after dam-break of tailing pool. // Journal of Nanchang Institute of Technology. 34, 1(2015), pp. 60-63.

[18] Zheng, X.; Kang. Y.; Xu, K. L.; Xu, X. H. Experiment study on tailings dam piping. // Industrial Safety and Environmental Protection. 39, 6(2013), pp. 37-39.

[19] Yin, G. Z.; Jing, X. F.; Wei, Z. A.; Li, X. S. study of model test of seepage characteristics and failure mechanism of coarse and fine tailings dam. // Chinese Journal of Rock Mechanics and Engineering. 29, A2(2010), pp. 3710-3718.

[20] Zhang, X. K.; Sun, E. J.; Li, Z. X. Experimental Study on Evolution Law of Tailings Dam Flood Overtopping. // China Safety Science Journal. 21, 7(2011), pp. 118-124.

[21] Zhang, L. T. Summary on the dam-break of tailings pond. // Journal of Hydraulic Engineering. 44, 5 (2013), pp. 594600.

[22] Chu, J. W.; Song, H. B.; Zhang, H. W. Experimental study on tailing dam break due to overtopping. // China Mining Engineering. 44, 3(2015), pp. 73-77.

[23] Yang, J. J. Similarity theory and structure models experiment. Wuhan University of Technology Press, Wuhan, 2005.

[24] Cermak, J. E. Physical-modeling investigations for wind engineering: Applications beyond wind-load determinations. // Journal of Wind Engineering and Industrial Aerodynamics. 36, 1(1990), pp. 39-52. https://doi.org/10.1016/0167-6105(90)90291-J

[25] Zhang, L. T.; Zhou, G. B.; Gu, F.; Qi, Q. L. Influence of the Rapidly Changing Reservoir Level on the Stability of Tailing Dam. // Metal Mine. 37, 8(2008), pp. 119-122.

[26] Zhang, Y.; Qin, W. X.; Zhang, Y. A. Reliability Analysis on Anti-sliding Stability for Dumulong Tailing Dam. // Metal Mine. 39, 5(2010), pp. 154-157.

[27] Zhang, J.; Cao, S. Y.; Yang, F. G.; Luo, L. H.; Huang, E. Experimental Study on Outlet and Scour of Blocked Dam. // Sichuan University (Engineering Science Edition). 42, 5(2010), pp. 191-196.

\section{Authors' addresses}

\section{Wang Guang-jin}

Corresponding author

Key Laboratory of Mine Geological Hazards Mechanism and Control, Shaanxi Institute of Geological Survey,

Xi'an 710054, China

wangguangjin2005@163.com

\section{Kang Jing-wen}

China Southwest Geotechnical Investigation \& Design Institute CO., Ltd., Chengdu 610052, China

kangjingwen007@163.com

\section{Du Chao}

China Southwest Geotechnical Investigation \& Design Institute CO., Ltd., Chengdu 610052, China chao_du@foxmail.com

\section{TangYong-jun}

Faculty of Land Resources Engineering,

Kunming University of Science and Technology,

Kunming 650093, China

kmtyj1992@163.com

\section{Kong Xiang-yun}

Faculty of Civil Engineering and Mechanics,

Kunming University of Science and Technology,

Kunming 650093, China

594270699@qq.com 